\title{
XLIII. On fossil calamites found standing in an erect position in the carboniferous strata near Wigan, Lancashire
}

\section{E.W. Binney}

To cite this article: E.W. Binney (1847) XLIII. On fossil calamites found standing in an erect position in the carboniferous strata near Wigan, Lancashire , Philosophical Magazine Series 3, 31:208, 259-266, DOI: $10.1080 / 14786444708562640$

To link to this article: http://dx.doi.org/10.1080/14786444708562640

曲 Published online: 30 Apr 2009.

Submit your article to this journal $₫$

Џll Article views: 4

Q View related articles $₫$ 
detected at once by the fine orange-red colour which the reagent assumes when it is heated in contact with that mineral.

A vanadiate gives a dark colour, but possessing less of the red shade than the molybdate. The liquor filtered from the sulphuret of lead containing the vanadium in solution has a green colour, becoming blue by the addition of hydrochloric acid. Hence it appears that arsenic dissolved in bisulphohydret of ammonia does not alter the colour of that reagent, while the liquor gives a precipitate of orpiment by concentration. Molybdenum and vanadium, on the other hand, render that reagent reddish, and give brown precipitates by concentration. The liquor filtered from the sulphuret of molybdenum is colourless, or its hue is similar to that of the reagent, while the liquor derived from the vanadium precipitate is green.

I have succeeded in decomposing a sufficient amount of these minerals for quantitative analysis by the preceding process when they have been carefully pounded and lævigated. The process is particularly advantageous in the analysis of molybdate of lead, where the use of nitric acid for dissolving the mineral is objectionable in consequence of its tendency to form the molybdate of molybdenum, and where hydrochloric acid, by producing a chloride of lead, renders the employment of an inconvenient quantity of water necessary. I have found this process for testing very convenient where it was desirable to use minute quantities of crystals, and where rapidity is an object in view, as in examining a large collection of minerals of the preceding description; and I mention it for the sake of those who may possess in their cabinets minerals of this nature which they may desire to test, since it may be found a useful adjunct to the blowpipe test.

The bisulpholnydret affords a simple distinguishing test between metallic arsenic and antimony, when spots have been received on porcelain by Marsh's process. Arsenic dissolves in the reagent, and Jeaves a yellow stain by evaporation. Antimony dissolves and leaves an orange stain. For this experiment it is convenient to use the inside of the cover of a porcelain crucible.

XLIII. On Fossil Calamites found standing in an erect position in the Carboniferous Strata near Wigan, Lancashive. By E. W. BINNEY*.

THE fragmentary condition of the great bulk of fossil 1 plants found imbedded in the coal measures has led many geologists to suppose that they had been drifted from adjoin-

* Read before the Literary and Philosophical Society of Manchester, July 6,1847 , and communicated by the Author. 
ing lands, and had not grown in the position in which they are now found. But although it is certain that plants which have been drifted by water generally present a broken appearance, it is equally true that plants grown upon the spots where they are now found, having been laid low by the action of currents of water, or weighed down and buried by the weight of mud or silt that had fallen upon them, afford similar appearances, so that great care must be taken before we conclude that a plant has not grown on the place where it is now found merely because we find it in fragments.

A few years ago the whole of the fossil flora was generally supposed to have been drifted. The first plant that was excepted from this rule and recovered its proper place was the Stigmaria, whose long stringy rootlets prevented it from being so conveniently drifted by currents as the advocates of the drift hypothesis could desire; therefore it was allowed to have grown where it is found.

When numbers of Sigillariæ were found standing erect on seams of coal, and their roots had not been traced to their extremities, it was at first attempted to refer them to accident, like the snags now found in the Mississippi and other rivers. However, a more careful observation of these fossils, and the great number in which they were found, at length induced geologists to admit that they must have grown where they are now met with. The discovery of the trees at Dixon Fold on the Manchester and Bolton Railway by Mr. John Hawkshaw, F.G.S., and so ably described by the late Mr. Bowman, F.G.S., in the first volume of the Transactions of the Manchester Geological Society, mainly contributed to establish this view, which has been since clearly proved by the certainty that Stigmariæ are the roots of Sigillariæ, as the fossil trees of St. Helens and Dukinfield testify.

As yet, however, Sigillaria was the only tree that to any extent could be said to have been discovered in situ.

In the present communication, it is intended to show that Calamites have been found standing erect on the places in which they grew by the side of Sigillariæ, and that the rootlets of the former very much resemble, if they are not identical with, those of the latter plant.

The rootlets of Calamites have been very correctly figured and described by Messrs. Lindley and Hutton in vol. i. pp. 78 and 79 of their Fossil Flora of Great Britain ; but it is believed by the writer that although numbers of erect Calamites have been observed in the coal-measures, still none of them to his knowledge have been described with their roots standing in the position in which they had grown. 
During an examination of the deep excavations through the coal-measures made in forming the Bury and Liverpool Railway in the vicinity of Wigan, I was so fortunate as to discover on the 21 st day of April last, in the Pemberton Hill cutting about two miles west of Wigan, not only a whole forest of Sigillariæ standing erect with their roots just as they had grown, but also many Calamites in a similar state of perfection.

The accompanying woodcut, fig. 1, representing a view of the south side of the railway cutting, will show the position in which the fossils occurred, although it is on an exaggerated scale, and the characters of the trees are not given.

Fig. 1.

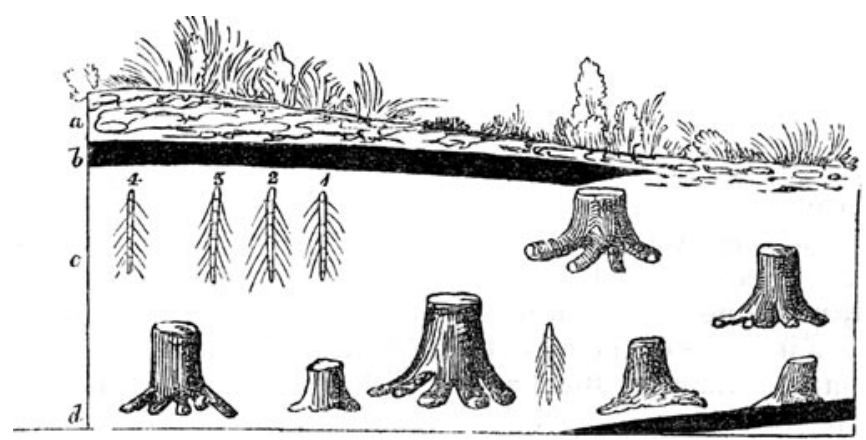

The excavation in which the fossils were met with is about twenty-five feet deep, and consists chiefly of a light graycoloured silty clay known by the provincial name of "Warren," containing nodules of ironstone. This deposit is very similar in composition to the strata in which the fossil trees at St. Helens and Dukinfield before described were found. It lies between two beds of coal each about two feet in thickness, and occupies a position in the higher part of the middle division of the Lancashire coal-field. The upper seam of coal is covered, and in some places partly removed, by a deposit of one or two yards in thickness of till. Near the bridge is seen a flexure in the strata, as shown in the woodcut.

In Mr. Haliburton's section at Haigh (vol. vi. New Series, of Manchester Memoirs, p. 437, Remarks on the Coal District of South Lancashire, by James Heywood, Esq., F.R.S.), occur the following strata:- 


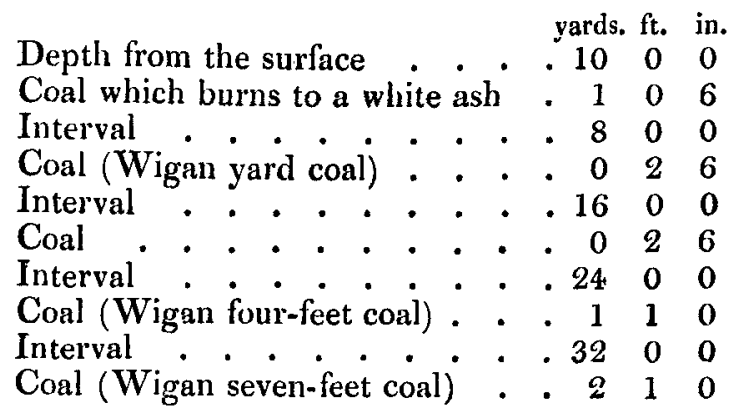

The interval of eight yards is in my opinion the deposit in which the fossil trees were met with.

In a distance of about fifty yards of the cutting, on my first visit to the place, I observed full thirty upright stems of Sigillaria, besides several flattened ones lying in a horizontal position. These trees exhibited no evidence of their former structure, being mere casts, having their insides filled with a similar material to the matrix in which they were found imbedded. Their outsides consisted of a coating of bright coal of about a quarter of an inch in thickness, and were ribbed and formed ns Sigillariæ usually are. In diameter they varied from one to three feet: their heights ranged from two to twelve feet; but, with one exception of a stem with another lying directly across it, none of them conld be traced to their termination upwards. Some of them rested with their stems on the top of the lower seam of coal; others had their roots midway between the two senms; and others again were found just under and in the floor of the upper seam. Most of the trees, which on exposure retained their coaly envelope, presented the irregularly ribbed and furrowed appearance which the Dixon Fold and St. Helen's trees exhibited, and which some geologists contend are not sufficient to identify them with Sigillaria; but six specimens were decorticated, and showed well-defined scars and all the other characters of Sigillaria reniformis, alternans and organum. All the upright trees had roots of Stigmarice with their rootlets traversing the silty clay in all directions.

Many stems of Calamites were found standing erect amongst the last-described trees, some of which were traced four and five feet in height without reaching their tops. These stems varied in diameter from one to five inches: they showed no structure internally, being mere casts filled with silty clay and having a coaly envelope of about one-sixth of an inch in thickness, which on being removed exposed the ribbed character 
and usual joints of this genus of plants. All those which could be traced downwards exhibited rootlets proceeding from the lower joints, less in size, but resembling those of Stigmariæ.

One of the erect Calamites was traced for about two feet upwards, and then at first sight appeared to terminate; but on more careful inspection it could be traced running in a horizontal direction, but so much compressed as to remain unseen without very close observation.

The erect stems both of undoubted Sigillarixe and trees which did not exhibit all the characters of Sigillariæ as well as those of Calamites, occurred in all parts of the deposit of silty clay, from the top of the lower seam to the floor of the upper one.

In the deposit where the trees occurred were found plants of the genera Neuropteris, Pecopteris, Sphenopteris, Cyclopteris, Odontopteris, Asterophyllites, Pinnularia, Lepidodendron, Lepidophyllum, Lepidostrobus, Lycopodites, Sphenophyllum, \&c.

Having thus given a hasty sketch of the locality where the fossils occurred, and the fossils themselves as they appeared to me on my first visit to the place, I shall proceed to describe some erect stems of Calamites, which are intended to form the chief subject of this communication. These trees were not only seen by myself, but by Dr. J. Hooker and M. Jobert, two well-known geologists; and it is to the latter gentleman that I am indebted for the drawings which accompany this paper.

On the 22nd of May last, in company with the above-named gentlemen, I again visited the Pemberton Hill cutting. Many erect specimens of Calamites, both with and without roots, had been seen on my previous visits to the place; but the three which it is now my intention to describe exhibited the lower terminations, and more distinctly showed the rootlets than the other specimens.

The three fossils marked Nos. 1, 2 and 3, in the rough sketch before given, and No. 4, an individual examined by me on a previous visit, occurred in the excavation on the south side of the railway. They were all found standing in an erect position about two yards distant from each other, having their tops, as far as bared, two yards under the upper seam of coal. They were each exposed from twenty inches to two feet, and all presented the same external characters with regard to their stems, joints, and rootlets, and most resembled the Calamites approximatus.

The description of No. 1 will serve for the other two.

This specimen appeared standing in the silty clay in a nearly 
erect position, with the exception of a slight bend in its upper part, as shown in the drawing. It was almost cylindrical, and measured twenty-one inches from the base to its bighest part, which was exposed. Its greatest diameter, which occurred near the top, was one and a half inches; it then tapered slightly towards the bottom, and terminated in a club-shaped end. The exterior was covered with a coating of fine coal of about one-eighth of an inch in thickness, which on being removed exposed the usual ribs, furrows and joints, characteristic of Calamites. The interior showed no trace of structure, being composed of the same kind of silty clay as the matrix in which the fossil was found.

The following is a sketch of No. 1 as it appeared in the cutting, one-eighth the natural size of the fossil. The upper part had been removed before we saw the specimen.

The joints or nodi were ten in number, and occurred at irregular distances, but nearer together at the upper and lower extremities than in the middle of the fossil.

At the joints small circular depressions were seen, from which proceeded rootlets. These could be traced from eight to eleven inches in length without reaching their terminations. They went down into the silty clay, the higher ones making an angle of about $15^{\circ}$ with the horizon; but the angle gradually increased as they went lower, until they at last described an Fig. 2.

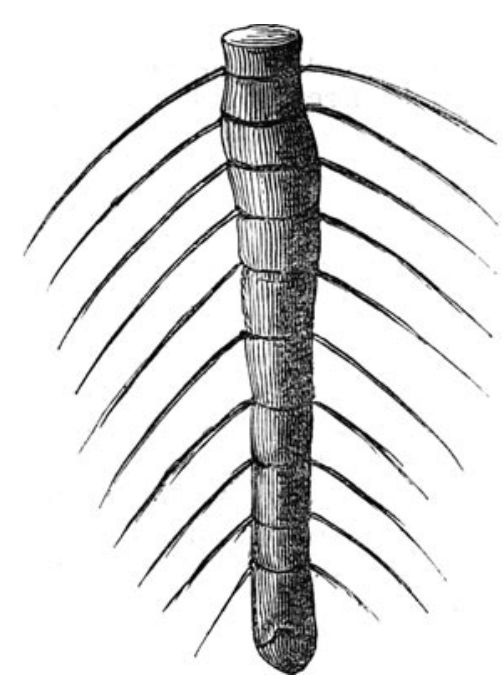
angle of about $45^{\circ}$.

The rootlets appeared to have been originally cylindrical and about one-eighth of an inch in diameter; but they were now compressed, and their outsides covered with a thin coating of carbonaceous matter. On a careful removal of the outside a delicate longitudinal stria could be perceived on the rootlets; there also appeared something like a pith in their middle.

Altogether the rootlets could not be well distinguished from those of Stigmaria. 'They also appeared to come from the 
stems in something like quircuncial order, like the rootlets of the last-named plant; but of this circumstance I cannot speak with absolute certainty.

The specimen No. 4 differed from the other three only in its base, which did not terminate in the same club-shaped extremity which they did; but after the joints had gradually approximated it turned inwards, and it could not then be seen whether it ended or was inserted into some other stem.

In addition to the above there were many Calamites, both in erect, inclined, and horizontal positions, but no leaves or branches were satisfactorily traced to them.

In the course of his examination of upright stems of Sigillariæ in the coal-measures, the writer has nearly always found Calamites associated with them. At St. Helens they were abundant, and their bases were found in contact with the main roots of Sigillariæ. One of the authors of the Fossil Flora, Mr. Hutton, in describing the Burdiehouse fossils at page 24, vol. iii. of that work, states as follows: "Amongst vegetables, the characteristic fossils of this deposit are Lepidostrobi, Lepidophyllites, Lepidodendra, and Filicites; the rarity of Calamites, which occur but seldom, and of a diminutive size, and the almost entire absence of Stigmaria, are very striking to those who are accustomed to view the fossil groups usually presented by the beds of the carboniferous formation; whilst the profusion of Lepidostrobi and Lepidophyllites of various sizes and in various stages of growth associated with the stems of Lepidodendra and those of no other plant, is an additional argument for the opinion which has always appeared highly probable, that they were the fruit, leaves and stem of the same tribe of plants. Of Sigillaria, a plant which in the flora of the carboniferous group generally is of so much importance, we could not observe a trace."

In the course of his own observations, the writer has never yet been able to meet with a stem of Sigillaria of so small a size as six inches in diameter, or a Calamites of so large a size as that. Doubtless there must have been young Sigillariæ whether or not there were large Calamites. Now what are young Sigillariæe? This is a question which yet remains to be answered.

It is now admitted that little is known about the true nature of the genera Sigillaria and Calamites, except that they were not the hollow succulent stems which they were once supposed to be.

The rootlets of Calamites, as previously shown, if not actually identical with, at least very much resemble those of Sigillaria. In some specimens of this latter genus, especially those 
of the species approximatus, figured and described in plate 216 , vol. iii. of the Fossil Flora, and the cruciatus, figured in plate 19 of Brongniart's Histoire des Végétaux Fossiles, their rootlets are arranged in regular quincuncial order. In the largest Calamites that to my knowledge has been figured, namely, that called Gigas, plate 27 in Brongniart's work before alluded to, the ribs and furrows begin to appear very like those of Sigillaria, and the joints show indistinctly. The termination of the root of a Calamites is exactly of the same form as the terminal point of a Stigmaria, both being club-shaped.

I am not aware that up to the present time much, if anything, is known of the structure of Calamites; but if it should resemble that of Sigillaria, it may tend to prove that Calamites are but young Sigillaria.

In our observations it must not however be lost sight of, that no central axis or pith has to my knowledge yet been discovered in the stem of the Calamites like that found in Sigillaria. Both plants are proved to have had similar habitats, and therefore it is very probable that they might have had rootlets resembling each other without being the same plant. Still, however, as Sigillaria was so long considered a separate plant from Stigmaria, it is unphilosophical to take no notice of the analogies of what are now considered distinct genera. Although it will not by any means be safe to affirm that Sigillaria and Calamites are the same plant from their analogies, still it is conceived that sufficient evidence has been adduced in this paper to prove that the latter as well as the former plants have generally grown on the places where they are now found, and that the reason why one is so much more frequently found in an erect position than the other, arises from the circumstance of the stem of the one being much stronger than that of the other. A deposit of mud on the branches and leaves of the slender stem of a Calamites might weigh it down and prostrate it, whilst the stout trunk of the Sigillaria would resist such action and continue erect.

XLIV. Upon the Chemical Constitution of Metacetonic Acid, and some other Bodies related to it. By E. FrankLAND, Esq. and H. Kolbe, Ph.D.*

THE researches into the constitution of organic compounds certainly belong to the most interesting in chemistry. But they are always attended with more or less danger, and those who, leaving the safer road of experiment, plunge into the depths of hypothesis, and build up theories apparently 1847. 